\title{
Government bond yield spreads determination: a matter of fundamentals or market overreaction? Evidence from over-borrowed European countries
}

\author{
Dimitris Vas. Seremetis \\ Associate Professor, University of the Aegean, Greece \\ Anastasios P. Pappas \\ Adjunct Lecturer, University of the Aegean, Greece
}

This paper examines through a panel data analysis the determinants of government bond yield spreads for over-borrowed European countries (Belgium, Italy, Ireland, Greece, Portugal, Spain) for the period 1990-2010. The results suggest that the aforementioned government bond yield spreads were significantly increased during international financial crises. On the other hand, domestic macroeconomic fundamentals appear to be negligible drivers of government bond yield spreads for the same period. A high debt-to-GDP ratio seems to be an important determinant of spreads only after 2007, when the subprime mortgage crisis had burst out and market sentiment became negative. Thus the paper presents some evidence that sharp bond spread fluctuations may be driven by financial markets' overreaction and investors' herd behaviour during international financial crises. Financial markets seemed to neglect the deterioration of macroeconomic fundamentals of the six European countries during tranquil periods and seemed to start discriminating more, between countries, during crises.

Keywords: government bond spreads, European countries, macroeconomic fundamentals, credit rating agencies, financial crises, panel data analysis

JEL codes: $E 43, G 01, G 12$

\section{INTRODUCTION}

Since the onset of the financial turmoil in Europe during 2009-2010, government bond yield spreads have fluctuated substantially. Most of the eurozone countries, especially those with high public-debt-to-gross-domestic-product ratios, encounter a significant widening of their sovereign risk premium differential. In particular, the spreads on the yield on long term Irish, Greek and Portuguese government bonds over the German Bunds increased significantly during 2009-2010 and skyrocketed in 2011. Under these adverse circumstances the aforementioned countries were forced to resort to tripartite financial aid from the European Commission, the European Central Bank and the International Monetary Fund. However, this bailout has not reduced considerably

Received 23 May 2012, accepted 11 July 2013 
the possibility of sovereign defaults within the euro area. The situation has become so dramatic that the break-up of the euro area has become a realistic scenario.

The most important force behind this financial disorder is supposed to be the unsustainable fiscal deficits and the consequent accumulation of public debt of the European countries. The fact that the public-debt-to-GDP ratio is increasing amplifies the possibilities of a sovereign default. Thus the increase of spread differential between a country with sustainable public debt and a country heavily indebted may be characterized as a rational outcome due to global investors' attitude towards higher sovereign risk. A disciplined country with sustainable public finances is rewarded by the markets with lower interest rates or lower government bond yield spreads compared to a benchmark such as, in our case, the German Bund. A considerable amount of empirical research confirms the positive relation between fiscal deficits and government bond yield spreads. Bernoth et al. (2004) conclude that the yield spreads respond significantly to indicators of government indebtedness. Additionally, Bernoth/Wolff (2006) found that risk premia contained in government bond spreads increase in both the official fiscal position and the expected 'creative' part of fiscal policy. Sgherri/Zoli (2009) show evidence that markets became more concerned about the potential fiscal implications of national financial sectors' frailty and future debt dynamics, especially during periods of high financial market volatility. Furthermore, Attinasi et al. (2009) find that higher expected budget deficits and/or higher government debt ratios relative to Germany contributed to higher government bond yield spreads in the euro area during the period 2007-2009.

However, one of the most intriguing characteristics of European sovereign debt crisis is the sensitivity of the European government bond yield spreads to events affecting investors' psychology and market sentiment. Downgrades of sovereign debt, political statements and events, estimations, even rumors can cause substantial fluctuations to the spreads in the euro area government bond market. Thus the European debt crisis may reflect not only the deterioration of macroeconomic fundamentals but market overreaction driven by negative investors' psychology and herd behaviour. Besides, the European financial turmoil gives space to international speculation since substantial profits may be exploited, mainly through three channels: purchasing of credit default swaps (CDS); short selling of government bonds; and purchasing of government bonds at the plummeted market prices. ${ }^{1}$ Therefore, the economic disorder may be desirable from cycles of speculation which may stoke rumors that push European government bond spreads upwards. Thus, according to this view, country-specific variation represents only a fraction of the total variation in European government bond spreads.

On the other hand, before the recent financial turmoil and especially during the period 1999-2007, markets seemed to underreact to news about the fiscal position of the euro area countries and to price sovereign risk quite low, even for countries with a heavy public debt burden. There are striking examples where government bond yield spreads of some European countries were totally diverging from economic fundamentals and especially from the public-debt-to-GDP ratio. Among many others, two particular cases are worth mentioning. In 1995, the Belgian government was borrowing at an interest rate only 0.4 percentage points higher than the rate at which the German Government was borrowing. The same year, Belgium had a public-debt-to-GDP ratio of 114 per cent while

1. The implicit guarantees which the IMF intervention gives for a full payback of international creditors may encourage the purchasing of government bonds at very low market prices (moral hazard). For instance, in May 2012 the Greek Government paid in full a government bond of $€ 430$ million (par value) that was excluded from the 'haircut' and was purchased at a very low market value. 


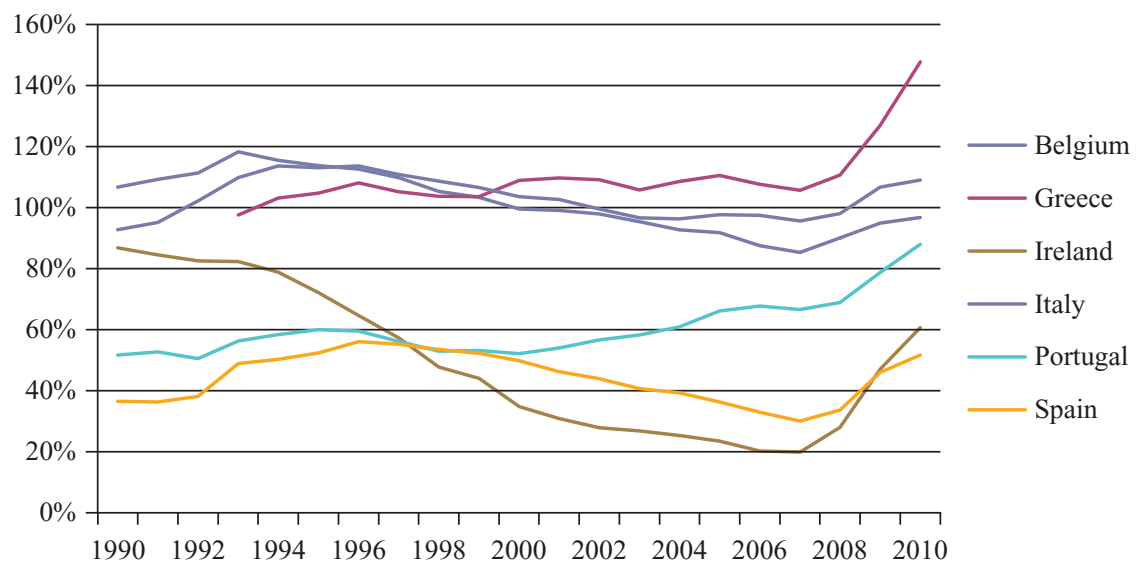

Source: OECD database.

Figure 1 Public debt in relation to GDP (1990-2010) in \%

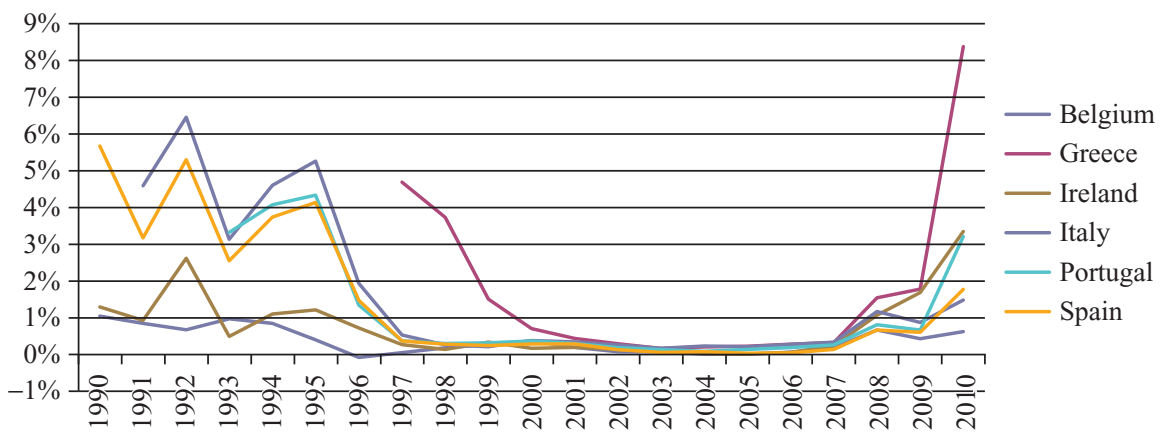

Source: OECD database.

Figure 2 Long-term government bond yield spreads (\%) of Belgium, Greece, Ireland, Italy, Portugal and Spain against Germany (1990-2010)

Germany's public-debt-to-GDP was only 21 per cent. In 2005, the Greek government was borrowing at only 0.22 per cent above the interest rate which the Irish government was borrowing from the financial markets. The public-debt-to-GDP ratio for these two economies was 111 per cent and 24 per cent respectively (see Figures 1 and 2). ${ }^{2}$

Indeed, descriptive statistics for the last 2 decades do not show a stable relation between public-debt-to-GDP ratios and government spreads for the European countries, most of which are now affected by the European debt crisis. Figure 3 reveals that spreads range mainly from 0 per cent to 2 per cent, irrespective of the public-debt-to-GDP ratio.

2. The figures reported by the OECD refer to the Central Government Debt as a percentage of GDP. 


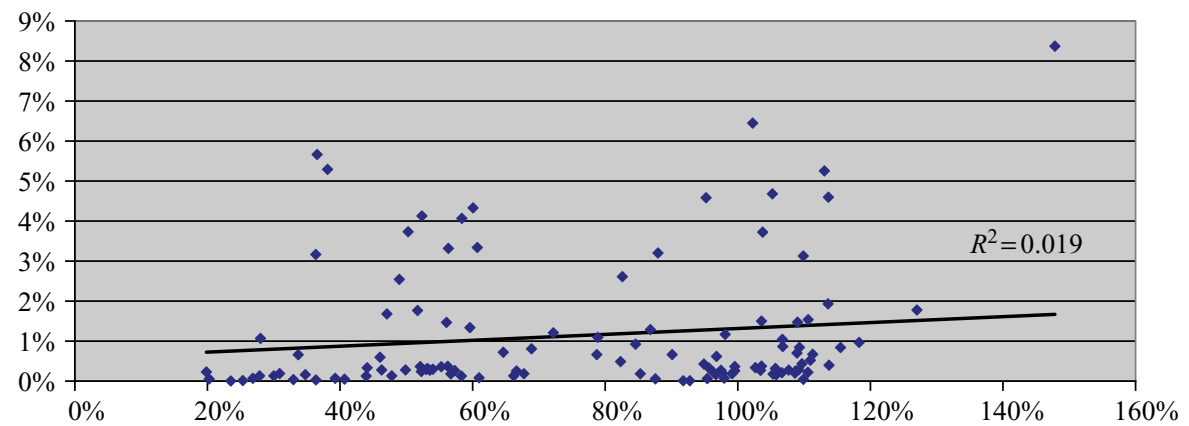

Source: Authors' calculations.

Figure 3 Ratio of long-term government bond yield spreads (\%) and public-debt-toGDP (\%) for Belgium, Greece, Ireland, Italy, Portugal and Spain (yearly data for 1990-2010)

1999-2007

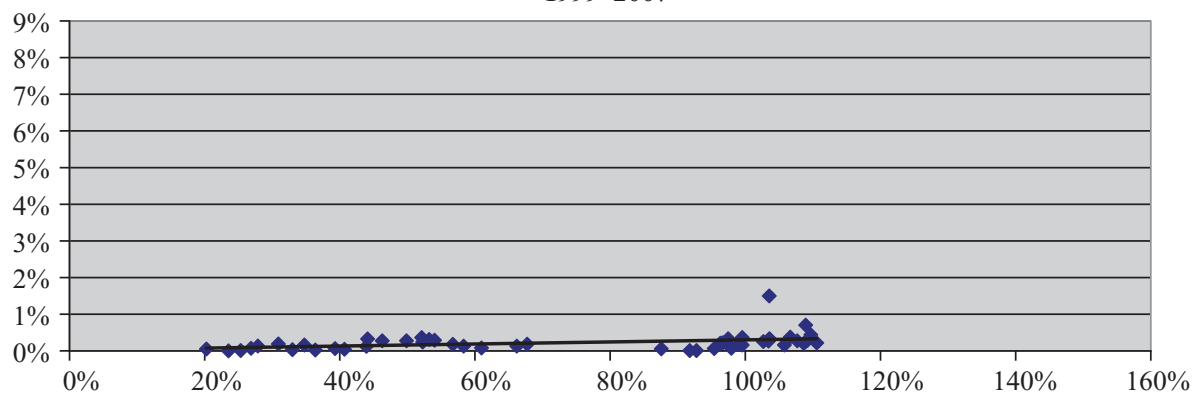

2007-2010

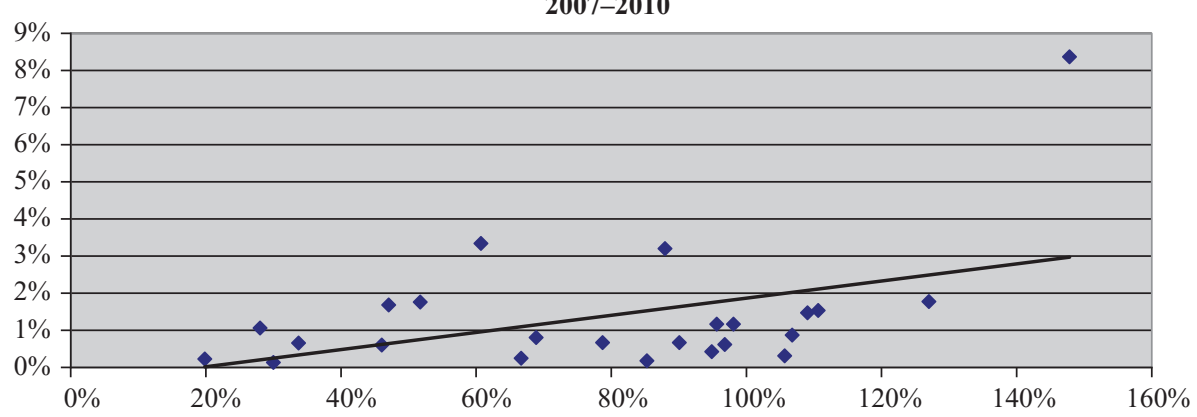

Source: Authors' calculations.

Figure 4 Ratio of long-term government bond yield spreads (\%) and public-debt-toGDP (\%) for Belgium, Greece, Ireland, Italy, Portugal and Spain (yearly data for 1999-2007 and 2007-2010)

The picture is more striking when the sample is divided into two time periods, 1999-2007 and 2007-2010 (see Figure 4). From 1999 to 2007, the period where 
euphoria was prevailing in the eurozone, government bond yield spreads were totally unrelated to the debt-to-GDP ratio. Debt-to-GDP ratios ranged from 20 per cent to 110 per cent, while spreads varied only by 1 percentage point at the most. After 2007, when financial markets became more fragile, spreads seemed more connected with the fluctuation of the public-debt-to-GDP ratio.

The view that market exaggeration is responsible for the widening in sovereign credit spreads is supported, among others, by Longstaff et al. (2007), Becker (2009) and De Grauwe/Ji (2012). More specifically, Longstaff et al. (2007) suggest that sovereign credit risk is driven much more by global financial market variables and global risk premia than by local economic forces. The writers attribute these results to the growing importance of globalization in the international economy. Moreover, Becker (2009: 11) concludes that, during times of financial crisis and global economic uncertainty, investors might prefer to invest their money in high-quality and very liquid, safe government bonds such as German Bunds. However, CDS market-implied probabilities appear high, suggesting that many other factors apart from default risks (macroeconomic fundamentals) also determine the pricing in these markets. Finally, De Grauwe/Ji (2012: 17) argue that a large part of the surge in the spreads of the weak economies of the eurozone during 2010-2011 was disconnected from underlying increases in the debt-to-GDP ratios, and was the result of negative market sentiment that became very strong after the end of 2010. After years of neglecting high debt-to-GDP ratios, investors became increasingly worried about the high debt-to-GDP ratios in the eurozone, and reacted by raising the spreads. Their paper finds evidence that the story of the eurozone is a story of systematic mispricing of the sovereign debt.

In this paper, we contribute to this line of research by investigating the government bond yield spreads determination drawing evidence from six over-borrowed European countries $^{3}$ for a 20 -year period from 1990 to 2010. Our aim is to examine whether the sharp spread widening is a reasonable market reaction, primarily reflecting increased risks in these economies due to the deterioration of macroeconomic fundamentals, or whether it is fuelled by market exaggeration, negative investors' psychology and financial contagion due to international financial crises.

The rest of the paper is structured as follows. In Section 2 the variables, data and econometric methods used in the paper are discussed. The empirical results are presented in Section 3; in Section 4, the results are re-examined, taking into consideration potential structural breaks; while Section 5 concludes the paper.

\section{METHODOLOGY VARIABLES AND DATA SET}

\subsection{The potential determinants}

The possible determinants of changes in European government bond spreads are categorized in four categories of explanatory variables.

The first category includes variables of domestic macroeconomic fundamentals. The most important variable is supposed to be the fiscal deficits. The accumulation of fiscal deficits increases the public-debt-to-GDP ratio and the possibility of a sovereign default. Thus, global investors' attitudes towards the increased credit risk may be

3. The sample includes Belgium, Greece, Ireland, Italy, Portugal and Spain. It has to be noted that Spain's public-debt-to-GDP ratio is quite moderate throughout the sample period. Nevertheless, Spain is at the core of the recent European crisis and is being closely monitored by Financial Markets, thus we considered that it must be included in the sample. 
reflected to higher spread yields. Moreover, the growth rate may affect the government bond yield spreads. The risk of sovereign default depends on the overall economic situation of a country. In an economic slow-down, government revenues decrease, and the probability of default may rise. Thus, lower growth or industrial production may be linked to higher spreads and the opposite. Another crucial variable may be the current account deficit, as long as the countries do not participate in a monetary union. If this is the case, large current account deficits may trigger a currency crisis and an increase in the probability of a default. Under this situation, the outcome may be a spread increase. The current account deficit is also linked with a higher probability of default within a monetary union. Since deficits in the current account imply an increase of external debt, the absence of an independent central bank excludes the possibility of seignioraging such debt by printing money. Thus the possibility of default within a monetary union increases substantially. Additionally, high inflation rates may inhibit growth because of the decline of international cost competitiveness and may therefore trigger a currency crisis if a national currency exists.

Except from macroeconomic indicators, fiscal-financial linkages may be an important determinant of European government bond yields. A deterioration of banks' portfolios may create implicit future government liabilities, since governments tend to bail out banks and socialize the losses of the banking system in order to avoid bank failures and a systematic increase in the fragility of the country's financial system. Thus, even if a government budget balance seems healthy, if the asset quality of the banking system is deteriorating, concerns over fiscal sustainability are intensified and yield spreads may rise.

Nevertheless, local economic variables may represent only a limited fraction of the total variation in European government bond spreads. Financial markets may overreact and push spreads upward without an important deterioration in domestic macroeconomic environments. We try to capture this market sentiment effect with the variables of the second category. These are the foreign reserves held by the central bank, the credit score from credit rating agencies - Moody's Ratings in particular - and a dummy related to the electoral cycle of each country. A sudden and considerable fall of foreign reserves may discourage investors from purchasing domestic bonds, since this is a signal for the deterioration of the external position of the country. On the other hand, the diachronic increase of foreign reserves gives the signal that the country becomes more and more competitive, thus increasing the confidence of investors to invest in sovereign debt. Additionally, the electoral cycle may increase the uncertainty of domestic and foreign investors to the extent that electoral competition gives rise to a debt or deficit bias, as the ruling party seeks to win elections and tie the hands of a potential successor. This increase in uncertainty may be reflected in higher yield spreads. Finally, the credit rating agencies may affect investors' psychology. The downgrading of a country's credit position, especially, may cause capital flight outside the country to safer shelters, forcing domestic government bond yield upward.

Liquidity factors may also affect government bond yield spreads. When financial uncertainty prevails, investors' preferences change towards more liquid assets. On the other hand, abundant liquidity undermines market discipline and that may be reflected in lower spreads between 'more disciplined' and 'less disciplined' economies. Especially in the euro area, the government bond market differs in terms of liquidity. The German bond market is the only one in Europe that has a liquid futures market, and this boosts demand for German Bunds also on the cash side compared to other euro area debt (Barrios et al. 2009: 7). Thus it is rational to suppose that, during times of low market liquidity, investors may abandon the peripheral European 
government bond for the more liquid German government bonds. The outcome of such investment behaviour is a spread increase. In contrast, the global liquidity glut may have pushed sovereign yield spreads in the euro area to converge at very low levels as investors' appetite for riskier investments fuels the demand for peripheral government bonds.

According to a considerable amount of research (Dungey et al. 2000; Bernoth et al. 2004; Pagano/Thadden 2004), interest rate differentials and bond yield spreads widen during global financial crises. Investors abandon peripheral economies and move to the safer and more liquid assets of big economies, causing bond yield spreads to increase. Therefore the fourth category includes variables in order to capture the effects of international financial crises to government bond yield spreads due to financial contagion.

\subsection{The econometric model}

To investigate empirically the determinants of the European government bond spreads, the following equation is estimated:

$$
r_{i t}=a_{0}+a_{1} Z_{i t}+a_{2} M_{i t}+a_{3} \text { Liq }_{t}+a_{4} \text { Crises }_{i t}+\varepsilon_{i t} .
$$

The dependent variable $r_{i t}$ is the change in the 10-year sovereign bond yield spread issued in EU country $i$ over the benchmark which is the German Bund. $Z_{i t}$ is a vector containing several variables related to macroeconomic fundamentals and a proxy variable of fiscal-financial linkages: fiscal balance, which is measured as a percentage of the GDP (FISCAL); growth, which is measured by the four-quarter rate of change of industrial production (IP); inflation rate, which is the four-quarter change in the consumer price index (CPI); current account balance, as a percentage of GDP (CA). In order to capture the linkages between implicit fiscal deficits and the deterioration of bank asset quality, the CREDIT variable is used. The aforementioned variable is reporting the domestic credit expansion. A significant credit expansion shows a flourishing economy, while a credit contraction indicates that banks tighten lending standards and constrain credit growth. A possible credit crunch reduces aggregate demand and deteriorates the economy's growth outlook. This intensifies concerns over fiscal sustainability, and sovereign spreads may rise. In addition, increased market concern means that governments are forced into more frontloaded fiscal consolidation, which further depresses near-term demand and growth. This in turn leads to a further deterioration of bank asset quality - owing to higher losses on sovereign debt holdings - and an increase in non-performing loans to the private sector, prompting further tightening in credit standards.

$M_{i t}$ is a vector containing variables which may affect the market sentiment such as the foreign reserves held by the central bank (RESERVES), the credit score on sovereign debt from credit rating agencies (and specifically Moody's Ratings) and a dummy related to the electoral cycle of each country. Electoral uncertainty may be captured by a dummy variable taking the value of one the quarter before national elections and zero otherwise (ELECTIONS). To capture the effects of changes in sovereign credit rating, an index is constructed based on the credit score of 'Moody's Ratings' for sovereign issuers (MOODY'S). The index takes the price of one for 'triple A' government bonds which have highest quality and the smallest degree of risk, falling to 0.25 for ' $\mathrm{C}$ ' rating which includes the lowest-rated class of bonds that are typically in default (see Table A4 and Figure A1 in the Appendix to this paper). 
$\mathrm{Liq}_{i t}$ is a proxy for liquidity in the European financial markets. It is calculated as the difference between the European Central Bank (ECB) interest rate for main refinancing operations and three-month EURIBOR. ${ }^{4}$ The size of the spread may indicate whether liquidity problems exist in the European financial markets. A rising spread - that is, the increasing EURIBOR towards the ECB rate - indicates that liquidity is being withdrawn.

Crises $_{i t}$ variables are dummies related to international financial crises and contagion effects. We introduce to the model dummies in order to consider the European Exchange Rate Mechanism Crisis of 1992 taking the value of one the second and the third quarter of 1992 and zero otherwise (ERM), the Mexican-Tequila Crisis of 1994-1995 taking the value of one the first two quarters of 1995 and zero otherwise (TEQUILA), the Southeast Asian Crisis of 1997 taking the value of one the two last quarters of 1997 and zero otherwise (ASIAN), the Russian Crisis of 1998 taking the value of one last quarter of 1998 and zero otherwise (RUSSIAN) and the Sub-Prime Mortgage Crisis of 2008 taking the value of one the three last quarters of 2008 (SUB-PRIME) and zero otherwise. ${ }^{5}$ Finally, $\varepsilon$ is the error term (see Table A5 in the Appendix).

We utilize the panel data technique of random effects after testing the results of fixed effects approached through a 'redundant fixed effect' test (see Tables A2 and A3) and correct the reported $t$-statistics with the White (1980) heteroskedasticityconsistent estimate of the covariance matrix. ${ }^{6}$

Data are tested by panel unit root tests in order to avoid spurious regressions. A considerable amount of literature (Maddala/Wu 1999; Choi 2001; Im et al. 2003) suggests that panel-based unit root tests have higher power than unit root on individual time series. Thus we conducted the IPS test (Im et al. 2003) and the ADF-Fisher test (Maddala/Wu 1999) to search for unit roots. Variables that are found to have unit root are estimated in first differences (implied by $\Delta$ ). See Table A1 in the Appendix.

\subsection{Robustness checks}

In order to examine the robustness of the results, the model is reformulated in two ways. First, in the basic linear model, the independent variable of the ratio of fiscal balance to GDP is replaced with the ratio of public debt to GDP. Increased publicdebt-to-GDP ratio increases the possibility of a sovereign default. The increased default possibility pushes government bond yield spreads higher, as creditors require a higher premium for holding riskier assets. ${ }^{7}$

Second, drawing from De Grauwe/Ji (2012), we add to the model the square of the debt variable, in order to explore the existence of a non-linear relationship between economic fundamentals and government bond yield spreads. The rationale for

4. Since ECB rates are available only from 1999 onwards, the discount rate of Deutsche Bundesbank is being used for the period 1990-1998.

5. The milestones for the crisis dummies are presented in the Appendix (Table A5).

6. Since the reported $t$-statistics are based on White's (1980) heteroskedasticity-consistent estimate of the covariance matrix, robust standard errors may not be consistent with assumptions of Hausman test variance calculations. Thus the redundant fixed effect test is used instead of the Hausman test. The null hypothesis of redundant fixed effects is strongly accepted, therefore a random-effects panel data model is estimated.

7. The debt-to-GDP ratio variable is frequently used by researchers as a potential determinant of government bond yield spreads. See, among others, Alesina et al. (1992), Attinasi et al. (2009), Barbosa/Costa (2010) and De Grauwe/Ji (2012). 
including the square of the debt variable is that bond spreads may react only when a certain threshold-debt-to-GDP level is exceeded. Thus, the higher the ratio of public debt to GDP becomes, the higher is the possibility of a sovereign default. The nonlinear model with the square of the debt variable is specified as follows:

$$
r_{i t}=a_{0}+a_{1} Z_{i t}+a_{2}\left(D E B T_{i t}\right)^{2}+a_{3} M_{i t}+a_{4} \text { Liq }_{t}+a_{5} \text { Crises }_{i t}+\varepsilon_{i t} .
$$

Panel regressions for different specifications are being run with and without constructed indexes and dummy variables in order to isolate the effects of variables concerning macroeconomic fundamentals and international liquidity. Another profit is that in this way possible multicollinearity problems are avoided. ${ }^{8}$

\subsection{Data set}

The data are unbalanced and used on a quarterly basis from 1990 to 2010 in order to obtain a significant number of observations. The countries that are included in the sample are Belgium, Greece, Ireland, Italy, Portugal and Spain. Data source is the OECD database, ${ }^{9}$ except for the fiscal variable (FISCAL) and domestic credit expansion variable (CREDIT), which are derived from the IMF International Financial Statistics database. ${ }^{10}$ Data for the fiscal variable are converted from yearly to quarterly frequency by interpolation. The interpolation was based on observations of government consumption expenditures, which are available on a quarterly basis, assuming that the fiscal balance follows the trend of government consumption expenditures. ${ }^{11}$

\section{ECONOMETRIC RESULTS}

Table 1 reports the coefficients, the standard errors - based on the White (1980) heteroskedasticity consistent estimate of the covariance matrix - and the $R^{2}$ for each of the regressions. According to our results, yield spreads of the six EU countries versus Germany were mainly affected by international financial crises. During financial crises, international investors may abandon peripheral European countries for safer shelters such as the German economy. This capital flight, which is regularly exacerbated by investors' herd behaviour, may explain the increase of the yield spread. Indeed, the crisis dummies coefficient is consistently positive and statistically significant across specifications. More specifically, four out of five international financial crises seem to play an important role in the determination of Belgian, Greek, Irish,

8. Such a problem may occur with the 'MOODY'S' variable. Since macro fundamentals are an important determinant of credit scores set by rating agencies, estimation results may suffer from a multicollinearity problem due to the possible correlation of Moody's index and the macroeconomic variables.

9. http://stats.oecd.org/Index.aspx.

10. IMF International Financial Statistics. The reason that the IMF database is used instead of the OECD database is that the variable of government consumption expenditures that is necessary for the interpolation of the fiscal variables was not available from the OECD database. The credit expansion variable was also not available from the OECD database.

11. Linear interpolation is frequently used in this line of research (see, for instance, Alexopoulou et al. 2009). However, linear interpolation creates a variable with a strong trend. This trend may cause spurious results. In order to avoid the trend problem and create observations closer to reality instead of linear interpolation we calculate the variable based on real quarterly data of government consumption expenditures, since they are an important determinant of the fiscal balance. 
Table 1 Determinants of European government bond yield spreads compared to German Bund (1990-2010)

\begin{tabular}{|c|c|c|c|c|c|c|}
\hline Model & $\begin{array}{c}\text { I - Baseline } \\
\text { (Fundamentals) }\end{array}$ & $\begin{array}{c}\text { I - Baseline } \\
(\text { All } \\
\text { variables })\end{array}$ & $\begin{array}{c}\text { II - Linear } \\
\text { (Fundamentals) }\end{array}$ & $\begin{array}{c}\text { II - Linear } \\
\text { (All } \\
\text { variables) }\end{array}$ & $\begin{array}{l}\text { III - Non-linear } \\
\text { (Fundamentals) }\end{array}$ & $\begin{array}{l}\text { III - Non-linear } \\
\text { (All variables) }\end{array}$ \\
\hline Constant & $\begin{array}{c}-0.0001 \\
(0.0005)\end{array}$ & $\begin{array}{c}-0.0004 \\
(0.0005)\end{array}$ & $\begin{array}{c}0.0001 \\
(0.0005)\end{array}$ & $\begin{array}{c}-0.0001 \\
(0.0006)\end{array}$ & $\begin{array}{c}0.0002 \\
(0.0005)\end{array}$ & $\begin{array}{c}0.0002 \\
(0.0006)\end{array}$ \\
\hline$\Delta$ (FISCAL) & $\begin{array}{c}-0.064 \\
(0.07)\end{array}$ & $\begin{array}{c}0.073 \\
(-0.086)\end{array}$ & - & - & - & - \\
\hline$\Delta(\mathrm{DEBT})$ & - & - & $\begin{array}{c}0.005 \\
(-0.005)\end{array}$ & $\begin{array}{c}-0.0058 \\
(0.0047)\end{array}$ & $\begin{array}{c}0.0024 \\
(0.0076)\end{array}$ & $\begin{array}{l}0.008 \\
(0.007)\end{array}$ \\
\hline$\Delta\left(\mathrm{DEBT}^{2}\right)$ & - & - & - & - & $\begin{array}{r}-0.072 \\
(0.037)\end{array}$ & $\begin{array}{l}-0.06 \\
(0.034)\end{array}$ \\
\hline IP & $\begin{array}{c}0.0075 \\
(0.0065)\end{array}$ & $\begin{array}{c}0.009 \\
(0.006)\end{array}$ & $\begin{array}{r}0.013 \\
(0.01)\end{array}$ & $\begin{array}{c}0.015 \\
(0.009)\end{array}$ & $\begin{array}{l}0.014 \\
(0.01)\end{array}$ & $\begin{array}{l}0.016 \\
(0.01)\end{array}$ \\
\hline$\Delta(\mathrm{CA})$ & $\begin{array}{c}0.0018 \\
(0.0013)\end{array}$ & $\begin{array}{c}0.0017 \\
(0.0014)\end{array}$ & $\begin{array}{c}0.0018 \\
(0.0015)\end{array}$ & $\begin{array}{c}0.0019 \\
(0.0016)\end{array}$ & $\begin{array}{l}0.002 \\
(0.0015)\end{array}$ & $\begin{array}{c}0.0021 \\
(0.0016)\end{array}$ \\
\hline CPI & $\begin{array}{c}-0.0168 \\
(0.0144)\end{array}$ & $\begin{array}{c}-0.023 \\
(0.014)\end{array}$ & $\begin{array}{c}-0.016 \\
(0.014)\end{array}$ & $\begin{array}{l}-0.023 \\
(0.0144)\end{array}$ & $\begin{array}{c}-0.016 \\
(0.015)\end{array}$ & $\begin{array}{c}-0.023 \\
(0.015)\end{array}$ \\
\hline CREDIT & $\begin{array}{c}-0.0005 \\
(0.0038)\end{array}$ & $\begin{array}{c}-0.0007 \\
(0.0037)\end{array}$ & $\begin{array}{c}0.0002 \\
(0.0044)\end{array}$ & $\begin{array}{c}-0.0005 \\
(0.0042)\end{array}$ & $\begin{array}{c}0.001 \\
(0.0047)\end{array}$ & $\begin{array}{c}0.001 \\
(0.004)\end{array}$ \\
\hline$\Delta(\mathrm{LIQ})$ & $\begin{array}{c}-0.259 \\
(0.204)\end{array}$ & $\begin{array}{r}-0.075 \\
(0.132)\end{array}$ & $\begin{array}{c}-0.332 \\
(0.219)\end{array}$ & $\begin{array}{r}-0.163 \\
(0.165)\end{array}$ & $\begin{array}{c}-0.335 \\
(0.215)\end{array}$ & $\begin{array}{r}-0.172 \\
(0.166)\end{array}$ \\
\hline$\Delta($ MOODYS $)$ & - & $\begin{array}{l}0.0006^{* * * *} \\
(0.00015)\end{array}$ & - & $\begin{array}{l}0.0007 * * * \\
(0.0002)\end{array}$ & - & $\begin{array}{l}0.0008 * * * \\
(0.0002)\end{array}$ \\
\hline ELECTIONS & - & $\begin{array}{c}-0.0005 \\
(0.0003)\end{array}$ & - & $\begin{array}{c}-0.0003 \\
(0.0002)\end{array}$ & - & $\begin{array}{c}-0.0003 \\
(0.0002)\end{array}$ \\
\hline$\Delta$ (RESERVES) & - & $\begin{array}{c}0.001 \\
(0.001)\end{array}$ & - & $\begin{array}{c}0.001 \\
(0.001)\end{array}$ & - & $\begin{array}{c}0.001 \\
(0.001)\end{array}$ \\
\hline ERM & - & $\begin{array}{l}0.009 * * * \\
(0.003)\end{array}$ & - & $\begin{array}{l}0.007 * * * \\
(0.002)\end{array}$ & - & $\begin{array}{l}0.0068^{* * * *} \\
(0.0022)\end{array}$ \\
\hline TEQUILA & - & $\begin{array}{l}0.0056^{* * * *} \\
(0.0021)\end{array}$ & - & $\begin{array}{l}0.0066^{* * * *} \\
(0.0008)\end{array}$ & - & $\begin{array}{l}0.0066^{* * * *} \\
(0.0008)\end{array}$ \\
\hline ASIAN & - & $\begin{array}{c}-0.001 \\
(0.001)\end{array}$ & - & $\begin{array}{c}-0.0011 \\
(0.0007)\end{array}$ & - & $\begin{array}{c}-0.0012 \\
(0.001)\end{array}$ \\
\hline RUSSIAN & - & $\begin{array}{l}0.0017 * * * \\
(0.0004)\end{array}$ & - & $\begin{array}{l}0.0017 * * * \\
(0.0005)\end{array}$ & - & $\begin{array}{l}0.0017 * * * \\
(0.001)\end{array}$ \\
\hline SUB-PRIME & - & $\begin{array}{l}0.0036^{* * * *} \\
(0.001)\end{array}$ & - & $\begin{array}{l}0.0034 * * * \\
(0.001)\end{array}$ & - & $\begin{array}{l}0.0033 \text { ** } \\
(0.001)\end{array}$ \\
\hline Obs & 357 & 357 & 287 & 287 & 287 & 287 \\
\hline$R^{2}$ & 0.03 & 0.13 & 0.01 & 0.15 & 0.02 & 0.16 \\
\hline
\end{tabular}

Notes:

1. The dependent variable is government bond yield spread.

2. Standard errors are reported into parentheses.

3. $* * *$ and $* *$ imply $1 \%$ and $5 \%$ significance level, respectively.

4. The standard errors are based on the White (1980) heteroskedasticity-consistent estimate of the covariance matrix.

Sources: OECD, IMF and author's calculations. 
Italian, Portuguese and Spanish government bond yield spreads vis-à-vis the German Bund. These are: the European Exchange Rate Mechanism crisis of 1992 (ERM); the Mexican Tequila Crisis of 1994-1995 (TEQUILA); the Russian Crisis of 1998 (RUSSIAN); and the Sub-Prime Mortgage Crisis of 2008 (SUB-PRIME). During these crisis episodes, there is a statistically significant rise in spreads, as is implied by the positive coefficients of the variables.

On the contrary, neither domestic macroeconomic fundamentals (public debt, fiscal balance, growth, inflation and current account balance) nor variables affecting further the market sentiment seem to play an important role for the spreads' determination in the six European countries. ${ }^{12}$ The findings indicate that international investors and creditors may neglect country-specific characteristics during tranquil economic periods and focus on negative facts or signals when economic turmoil is prevailing. This market overreaction may explain partly the recent European Debt Crisis. This does not necessarily mean that the over-borrowed European countries do not suffer from macroeconomic, structural or institutional weaknesses. The results may imply that these weaknesses are being examined more closely from international investors and creditors during periods with economic instability. Investors' and creditors' herd behaviour and international speculation may cause the situation to deteriorate.

\section{STRUCTURAL BREAKS}

The period under examination (1990-2010) has two crucial milestones. First, the creation of the eurozone, at the end of the 1990s; and, second, the outbreak of the global financial crisis of 2007-2008. These two milestones may indicate two structural breaks. The scatter plot from Figure 4 revealed a different pattern for the relation between public-debt-to-GDP ratio and bond spreads for different time periods. The fact that the simple regression line for the period 1999-2007 is almost parallel to the $\mathrm{x}$-axis reveals that bond spreads were unrelated to economies' public debt burden. It seemed that financial markets neglected the data for the public debt of the six European economies and relied on other factors in the decision to finance them. On the contrary, from 2007 to 2010, the slope of the simple regression line becomes sharper and shows an upward inclination, which indicates a stronger positive link between the two variables. However, further evidence is necessary in order to confirm the aforementioned relation of the two variables for the period 2007-2010.

In order to investigate whether a structural break exists in 1999 and 2007, a chow breakpoint test is conducted (see Table A6). The test reveals that there is indeed a structural break in the first quarter of 1999 and in the second quarter of 2007, a fact that allows us to conduct panel regressions for two sub-periods: 1999-2007 and 2007-2010.

The results of the panel regressions are reported in Table 2. They reveal that the public debt level, measured by the square of the public debt variable, is highly significant during the period 2007-2010. By contrast, during the period 1999-2007, the variables concerning the sovereign fiscal position are insignificant, and the highly significant variable is the current account deficit. The results indicate that financial markets indeed neglect the fiscal position of euro-area countries during the tranquil period of 1999-2007. Government bond yield spread differentials were determined irrespective

12. The MOODY'S variable is found to be significant; however, the sign of its coefficient is opposite from the expected. 
Table 2 Determinants of European government bond yield spreads compared to German Bund (1999-2007 and 2007-2010)

\begin{tabular}{|c|c|c|c|c|c|c|}
\hline \multirow[t]{2}{*}{ Model } & \multicolumn{3}{|c|}{ 1999-2007 } & \multicolumn{3}{|c|}{ 2007-2010 } \\
\hline & $\begin{array}{c}\text { I - Baseline } \\
\text { (Fundamentals) }\end{array}$ & $\begin{array}{c}\text { II - Linear } \\
\text { (Fundamentals) }\end{array}$ & $\begin{array}{l}\text { III - Non-linear } \\
\text { (Fundamentals) }\end{array}$ & $\begin{array}{c}\text { I - Baseline } \\
\text { (Fundamentals) }\end{array}$ & $\begin{array}{c}\text { II - Linear } \\
\text { (Fundamentals) }\end{array}$ & $\begin{array}{l}\text { III - Non-linear } \\
\text { (Fundamentals) }\end{array}$ \\
\hline Constant & $\begin{array}{c}0.0001 \\
(0.00015)\end{array}$ & $\begin{array}{c}0.0003 \\
(0.0002)\end{array}$ & $\begin{array}{c}0.0003 \\
(0.0002)\end{array}$ & $\begin{array}{c}-0.0002 \\
(0.0012)\end{array}$ & $\begin{array}{c}0.0007 \\
(0.0014)\end{array}$ & $\begin{array}{c}0.0008 \\
(0.0017)\end{array}$ \\
\hline$\Delta($ FISCAL $)$ & $\begin{array}{c}-0.023 \\
(0.019)\end{array}$ & - & - & $\begin{array}{c}-0.254 \\
(0.185)\end{array}$ & - & - \\
\hline$\Delta(\mathrm{DEBT})$ & - & $\begin{array}{c}0.005 \\
(0.005)\end{array}$ & $\begin{array}{c}0.0013 \\
(0.0044)\end{array}$ & - & $\begin{array}{c}-0.009 \\
(0.008)\end{array}$ & $\begin{array}{c}-0.004 \\
(0.014)\end{array}$ \\
\hline$\Delta\left(\mathrm{DEBT}^{2}\right)$ & - & - & $\begin{array}{l}0.04 \\
(0.101)\end{array}$ & - & & $\begin{array}{l}0.124 * * * \\
(0.041)\end{array}$ \\
\hline IP & $\begin{array}{c}0.002 \\
(0.002)\end{array}$ & $\begin{array}{c}0.003 \\
(0.003)\end{array}$ & $\begin{array}{c}0.003 \\
(0.003)\end{array}$ & $\begin{array}{l}0.02 \\
(0.016)\end{array}$ & $\begin{array}{r}0.0229 \\
(0.017)\end{array}$ & $\begin{array}{c}-0.004 \\
(0.028)\end{array}$ \\
\hline$\Delta(\mathrm{CA})$ & $\begin{array}{l}0.0018 * * \\
(0.0009)\end{array}$ & $\begin{array}{l}0.002 * * \\
(0.0008)\end{array}$ & $\begin{array}{c}0.002 * * \\
(0.0008)\end{array}$ & $\begin{array}{c}0.0004 \\
(0.002)\end{array}$ & $\begin{array}{c}0.001 \\
(0.003)\end{array}$ & $\begin{array}{c}0.0035 \\
(0.0043)\end{array}$ \\
\hline CPI & $\begin{array}{c}-0.005 \\
(0.005)\end{array}$ & $\begin{array}{c}-0.002 \\
(0.006)\end{array}$ & $\begin{array}{c}-0.0019 \\
(0.006)\end{array}$ & $\begin{array}{c}0.022 \\
(0.019)\end{array}$ & $\begin{array}{c}-0.0003 \\
(0.021)\end{array}$ & $\begin{array}{l}0.063 * * \\
(0.028)\end{array}$ \\
\hline CREDIT & $\begin{array}{c}-0.001 \\
(0.001)\end{array}$ & $\begin{array}{l}-0.001 \\
(0.0013)\end{array}$ & $\begin{array}{c}-0.0007 \\
(0.0055)\end{array}$ & $\begin{array}{c}0.0097 \\
(0.0098)\end{array}$ & $\begin{array}{c}0.015 \\
(0.008)\end{array}$ & $\begin{array}{l}-0.419 \\
(0.295)\end{array}$ \\
\hline$\Delta(\mathrm{LIQ})$ & $\begin{array}{l}0.02 \\
(0.032)\end{array}$ & $\begin{array}{c}-0.011 \\
(0.039)\end{array}$ & $\begin{array}{c}-0.011 \\
(0.037)\end{array}$ & $\begin{array}{c}-0.373 \\
(0.319)\end{array}$ & $\begin{array}{c}-0.505 \\
(0.369)\end{array}$ & $\begin{array}{l}-0.01 \\
(0.02)\end{array}$ \\
\hline Obs & 173 & 173 & 173 & 60 & 60 & 60 \\
\hline$R^{2}$ & 0.04 & 0.04 & 0.04 & 0.24 & 0.06 & 0.24 \\
\hline
\end{tabular}

Notes:

1. The dependent variable is government bond yield spread.

2. Standard errors are reported in parentheses.

3. $* * *$ and $* *$ imply $1 \%$ and $5 \%$ significance level, respectively.

4. The standard errors are based on the White (1980) heteroskedasticity-consistent estimate of the covariance matrix.

Sources: OECD, IMF and author's calculations. 
of the size of fiscal deficits or the public-debt-to-GDP ratio. A crucial determinant, according to the results, was the current account balance. Financial markets seem to be concerned more with the low competitiveness of some eurozone countries, which is reflected in higher current account deficits, than their fiscal deficits and public debt. On the contrary, during the highly volatile period of 2007-2010, the publicdebt-to-GDP ratio becomes the most crucial parameter of the determination of government bond yield spreads. The fact that the square of the debt variable is significant means that bond spreads react only when a certain threshold-debt-to-GDP level is exceeded; the public-debt-to-GDP ratio has a substantially higher impact on the yield spread when the ratio is high.

\section{CONCLUSIONS}

This paper has provided an empirical analysis of the determinants of spreads in the euro area government bond market, focusing on the six European countries which are at the centre of interest during current European debt crisis: Belgium, Greece, Ireland, Italy, Portugal and Spain, compared to the German economy. We find strong evidence that during the international financial crisis the aforementioned spreads were increased substantially, a fact that indicates a possible market overreaction unrelated to macroeconomic fundamentals. Furthermore, the majority of macroeconomic fundamental variables, such as the growth rate, the inflation rate and the domestic credit expansion, proved insignificant in explaining spreads determination during 1990-2010. As long as variables of countries' fiscal positions are considered, we found that the public-debt-to-GDP ratio plays a significant role in spreads determination only after 2007, when the international economic environment deteriorated due to the outbreak of the sub-prime mortgage crisis. On the contrary, financial markets had not taken into account the debt-to-GDP ratio during the 1999-2007 period when government bond yield spreads were considerably converged, in spite of the substantial differences of public-debt-to-GDP ratios across eurozone countries.

These results do not necessarily imply that the over-borrowed European countries did not suffer from macroeconomic, structural or institutional weaknesses. However, according to our results, these weaknesses seem to be neglected during tranquil economic periods when general euphoria is prevailing. During these periods, financial markets may underreact to the deterioration of macroeconomic fundamentals and particularly to the high public-debt-to-GDP ratio. When the international economic environment deteriorates, financial markets start monitoring domestic economic characteristics more closely and 'discovering' serious weaknesses, such as the heavy public debt burden. As a result, capital takes flight to safer shelters, such as German Bunds. This capital flight explains the spreads' increase. Spreads in the periphery may skyrocket when herd behaviour prevails and market is being driven by the speculative 'hot money'.

Currently, international investors, international creditors and credit rating agencies are supposed to monitor thoroughly the macroeconomic fundamentals and particularly fiscal deficits and the public debt of European countries. However, our findings show that, in general, this has not been the main challenge of financial markets during the last twenty years. Financial markets tend to underreact and overreact in particular time periods. Measures in order to 'throw some sand in the wheels of international financial markets' (Tobin 1978: 154) have been introduced into the political agenda. However, 5 years after the sub-prime mortgage crisis and 3 years after the European debt crisis, very few steps have been made towards such intervention. 


\section{REFERENCES}

Alesina, A., De Broeck, M., Prati, A., Tabellini, G. (1992): Default risk on government debt in OECD countries, in: Economic Policy, 15, 427-451.

Alexopoulou, I., Bunda, I., Ferrando, A. (2009): Determinants of government bond spreads in new EU countries, ECB Working Paper Series No 1093, September.

Attinasi, M., Checherita, C., Nickel, C. (2009): What explains the surge in euro area sovereign spreads during the financial crisis of 2007-2009, ECB Working Paper Series No 1131, December.

Barbosa, L., Costa, S. (2010): Determinants of sovereign bond yield spreads in the euro area in the context of the economic and financial crisis, in: Economic Bulletin, Banco de Portugal, Autumn, 131-150.

Barrios, S., Iversen, P., Lewandowska, M., Setzer, R. (2009): Determinants of intra-euro-area government bond spreads during the financial crisis, European Commission, Directorate General for Economic and Financial Affairs, Economic Papers No. 388.

Becker, S. (2009): EMU sovereign spread widening: reasonable market reaction or exaggeration?, Deutsche Bank Research, Reports on European integration, EU Monitor 68, June.

Bernoth, K., Von Hagen, J., Schuknecht, L. (2004): Sovereign risk premia in the European government bond market, ECB Working paper, No 369, June.

Bernoth, K., Wolff, G.B. (2006): Fool the markets? Creative accounting, fiscal transparency and sovereign risk premia, Deutsche Bundesbank, Discussion Paper No 19.

Choi, I. (2001): Unit root tests for panel data, in: Journal of International Money and Finance, 20, 249-272.

De Grauwe, P., Ji, Y. (2012): Mispricing of sovereign risk and multiple equilibria in the eurozone, CEPS Working Document, No 361, January.

Dungey, M., Martin, V., Pagan, A.P. (2000): A multivariate latent factor decomposition of international bond yield spreads, in: Journal of Applied Econometrics, 15, 697-715.

Im, K.S., Pesaran, M.H., Shin, Y. (2003): Testing for unit roots in heterogeneous panels, in: Journal of Econometrics, 115, 53-74.

Longstaff, F.A., Pan, J., Pedersen, L.H., Singleton, K.J. (2007): How sovereign is sovereign credit risk?, NBER Working Paper No 13658.

Maddala, G.S., Wu, S. (1999): A comparative study of unit root tests with panel data and a new simple test, in: Oxford Bulletin of Economics and Statistics, 61, 631-652.

Pagano, M., Thadden, E.-L.V. (2004): The European bond markets under EMU, in: Oxford Review of Economic Policy, 20(4), 531-554.

Sgherri, S., Zoli, E. (2009): Euro area sovereign risk during the crisis, IMF Working Paper $\mathrm{WP} / 09 / 222$.

Tobin, James (1978): A proposal for international monetary reform, in: Eastern Economic Journal, 4, 153-159.

White, H. (1980): A heteroskedasticity-consistent covariance matrix estimator and a direct test for heteroskedasticity, in: Econometrica, 48, 817-838. 


\section{APPENDIX}

Table Al Panel unit root tests

\begin{tabular}{|c|c|c|c|c|}
\hline \multirow[t]{2}{*}{ Variable } & \multicolumn{2}{|c|}{ IPS Test } & \multicolumn{2}{|c|}{ ADF-Fisher } \\
\hline & $\begin{array}{l}\text { Individual } \\
\text { effects }\end{array}$ & $\begin{array}{l}\text { Individual linear } \\
\text { trends }\end{array}$ & $\begin{array}{l}\text { Individual } \\
\text { effects }\end{array}$ & $\begin{array}{l}\text { Individual linear } \\
\text { trends }\end{array}$ \\
\hline Spread & $0.089 \mathrm{X}$ & $4.33576 \mathrm{X}$ & 30.8217 & $11.0092 X$ \\
\hline$\Delta($ Spread $)$ & $-9.374 * * *$ & $-12.63 * * *$ & $93.73 * * *$ & $143.01 * * *$ \\
\hline Reserves & $0.961 X$ & $0.932 \mathrm{X}$ & $1.8 \mathrm{E}-05 \mathrm{X}$ & 7.9E-08X \\
\hline$\Delta$ (Reserves) & $-2.84330 * * *$ & $-2.20792 * * *$ & $37.0536 * * *$ & $31.8171 * * *$ \\
\hline IP & $-18.99 * * *$ & $-19.19 * * *$ & $129.96 * * *$ & $226.34 * * *$ \\
\hline $\mathrm{CA}$ & $-0.444 X$ & $-2.87402 \mathrm{X}$ & $11.0873 X$ & $31.5784 X$ \\
\hline$\Delta(\mathrm{CA})$ & $-24.738 * * *$ & $-24.936 * * *$ & $159.15 * * *$ & $168.92 * * *$ \\
\hline CPI & $-4.14685 * *$ & $-1.57838 *$ & $44.4708 * * *$ & $21.7864 * *$ \\
\hline Fiscal & $-0.22 \mathrm{X}$ & $3.92 X$ & $9.969 X$ & $2.283 \mathrm{X}$ \\
\hline D(Fiscal) & $-11.87 * * *$ & $88.1 * * *$ & $-12.3 * * *$ & $157.78 * * *$ \\
\hline MOODYS & $0.114 \mathrm{X}$ & $1.396 X$ & $8.749 X$ & $6.866 X$ \\
\hline$\Delta($ MOODYS $)$ & $-14.54 * * *$ & $-17.09 * * *$ & $106.55 * * *$ & $192.97 * * *$ \\
\hline LIQ & $-1.03 X$ & $3.9 \mathrm{X}$ & $-0.55 X$ & $2.55 X$ \\
\hline$\Delta(\mathrm{LIQ})$ & $-9.04 * * *$ & $29.65 * * *$ & $-9.13 * * *$ & $46.7 * * *$ \\
\hline Debt & $-1.09 X$ & $21.67 *$ & $-2.55 X$ & $14.82 X$ \\
\hline$\Delta(\mathrm{Debt})$ & $-6.29 * * *$ & $86.12 * * *$ & $-6.44 * * *$ & $92.6 * * *$ \\
\hline Credit & $-13.43 * * *$ & $107.99 * * *$ & $-12.98 * * *$ & $163.29 * * *$ \\
\hline
\end{tabular}

Notes:

1. IPS test refers to Im et al. (2003) W-stat. The test assumes asymptotic normality.

2. The Augmented Dickey Fuller-Fisher test has been proposed from Maddala/Wu (1999). Probabilities for Fisher tests are computed using an asymptotic Chi-square distribution.

3. X implies a unit root.

4. ***, $* *, *$ imply that the null hypothesis of a unit root is rejected at a $1 \%, 5 \%$ and $10 \%$ level, respectively.

Source: Author's calculations.

Table A2 Redundant fixed effect test (period 1990-2010)

\begin{tabular}{ccccccc}
\hline Model & $\begin{array}{c}\text { I - Baseline } \\
\text { (Fundamentals) }\end{array}$ & $\begin{array}{c}\text { I - Baseline } \\
\text { (All variables) }\end{array}$ & $\begin{array}{c}\text { II - Linear } \\
\text { (Fundamentals) }\end{array}$ & $\begin{array}{c}\text { II - Linear } \\
\text { (All variables) }\end{array}$ & $\begin{array}{c}\text { III - Non-linear } \\
\text { (Fundamentals) }\end{array}$ & $\begin{array}{c}\text { III Non-linear } \\
\text { (All variables) }\end{array}$ \\
\hline$p$-values & 0.458 & 0.271 & 0.39 & 0.14 & 0.705 & 0.35 \\
\hline
\end{tabular}

Notes:

1. Null hypothesis: the cross-section fixed effects are redundant.

2. Null hypothesis is not rejected in any of the models, which means that the fixed effect model is inappropriate for our case.

Source: Author's calculations. 
Table A3 Redundant fixed effect test (periods: 1999-2007 and 2007-2010)

\begin{tabular}{cccccccc}
\hline Model & \multicolumn{3}{c}{$1999-2007$} & & \multicolumn{3}{c}{$2007-2010$} \\
\cline { 2 - 4 } \cline { 6 - 7 } & $\begin{array}{c}\text { I - Baseline } \\
\text { (Fundamentals) }\end{array}$ & $\begin{array}{c}\text { II - Linear } \\
\text { (Fundamentals) }\end{array}$ & $\begin{array}{c}\text { III - Non-linear } \\
\text { (Fundamentals) }\end{array}$ & $\begin{array}{l}\text { I - Baseline } \\
\text { (Fundamentals) }\end{array}$ & $\begin{array}{c}\text { II - Linear } \\
\text { (Fundamentals) }\end{array}$ & $\begin{array}{c}\text { III - Non-linear } \\
\text { (Fundamentals) }\end{array}$ \\
\hline$p$-values & 0.57 & 0.93 & 0.94 & 0.9 & 0.95 & 0.9 \\
\hline
\end{tabular}

Notes:

1. Null hypothesis: the cross-section fixed effects are redundant.

2. Null hypothesis is not rejected in any of the models, which means that the fixed effect model is inappropriate for our case.

Source: Author's calculations.

Table A4 Index for changes in sovereign credit rating based on Moody's Ratings score

\begin{tabular}{ll}
\hline Rating & Score \\
\hline Aaa & 1 \\
Aa1 & 0.95 \\
Aa2 & 0.925 \\
Aa3 & 0.9 \\
A1 & 0.85 \\
A2 & 0.825 \\
A3 & 0.8 \\
Baa1 & 0.75 \\
Baa2 & 0.725 \\
Baa3 & 0.7 \\
Ba1 & 0.6 \\
Ba2 & 0.575 \\
Ba3 & 0.55 \\
B1 & 0.5 \\
B2 & 0.475 \\
B3 & 0.45 \\
Caa1 & 0.4 \\
Caa2 & 0.375 \\
Caa3 & 0.35 \\
Ca & 0.3 \\
C & 0.25 \\
\hline
\end{tabular}

Sources: Moody's, author's calculations. 
Table A5 The milestones for crisis dummies

Exchange Rate
Mechanism Crisis of
1992

The Mexican-Tequila

Crisis of 1994-1995

The Southeast Asian

Crisis of 1997

The Russian Crisis of 1998

The Sub-Prime Mortgage Crisis of 2008
June 1992

September 1992

January 1995

July 1997

August 1998

September 2008
The rejection of the Maastricht Treaty from Denmark.

Black Wednesday: Withdrawal of the pound sterling from the European Exchange Rate Mechanism.

Collapse of the Mexican peso and default to external debt.

The collapse of the Thai baht, triggering currency crisis in Thailand.

The Russian government devalue the ruble, default on domestic debt, and declare a moratorium on payment to foreign creditors.

The Bankruptcy of Lehman Brothers.

Table A6 Chow breakpoint test (f-critical and f-statistical)

\begin{tabular}{ccccc}
\hline & F-critical & $\begin{array}{c}\text { I - Baseline } \\
\text { (Fundamentals) }\end{array}$ & $\begin{array}{c}\text { II - Linear } \\
\text { (Fundamentals) }\end{array}$ & $\begin{array}{c}\text { III - Non-linear } \\
\text { (Fundamentals) }\end{array}$ \\
\hline 1999 & $\mathrm{~F}(7,268)=2.04$ & 11.5 & 68.9 & 58.8 \\
2007 & $\mathrm{~F}(7,57)=2.17$ & 2.43 & 14.6 & 12.5 \\
\hline
\end{tabular}

Note: Since f-statistical $>\mathrm{f}$-critical, the hypothesis that the parameters are stable is rejected for significance level of $5 \%$.

Source: Author's calculations.

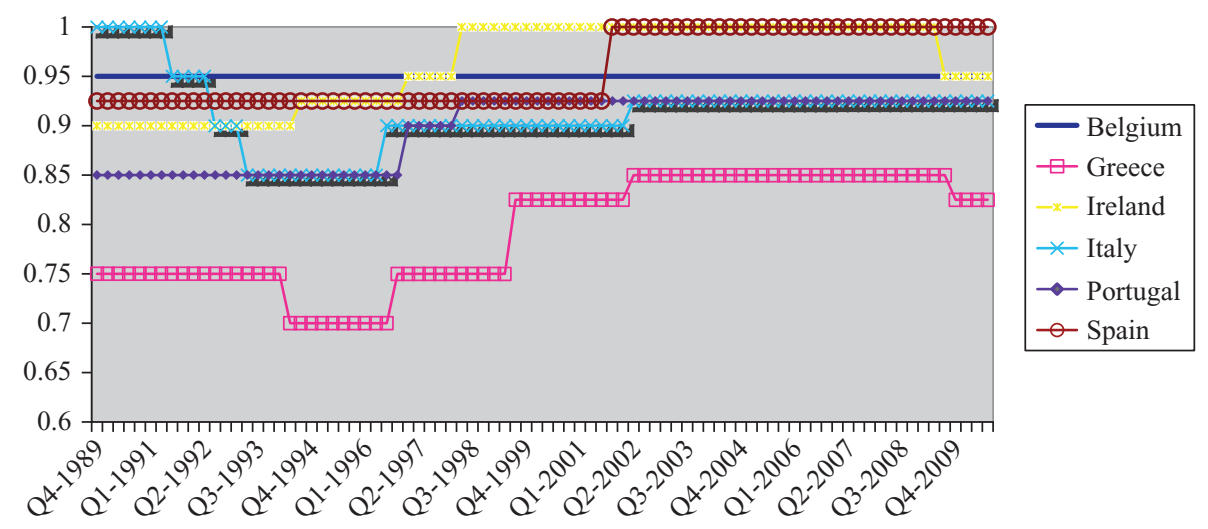

Source: Moody's.

Figure A1 Changes in sovereign credit rating for Belgium, Greece, Ireland, Italy, Portugal and Spain (1990-2010) 